\title{
HERMENEUTIKA HADIS ABŪ SYUQQAH
}

\author{
Oleh: \\ Hanief Monady \\ Universitas Islam Negeri Antasari, Banjarmasin
}

\begin{abstract}
In the study of Islamic thought in modern times, hermeneutics is a new trend that previously got less attention from Muslim scholars. Hermeneutics began widely discussed after many writings and works emerged from contemporary Arab writers and scholars. While according to hadiths, hermeneutics is everything that is copied from the Prophet, either in words, deeds, taqrir, as well as the properties of the Prophet before he became an apostle, or afterwards. One of the Muslim leaders who sees hermeneutics as a philosophy about how to understand the verses of the Qur'an and the Hadith is Abū Syuqqah. The author of this paper tries to reveal how Abū Syuqqah interpret and provide an understanding of the hadith of the Prophet Muhammad SAW, as well as the author seeks to explain the structure of hermeneutical in his understanding. As the findings, the writer extracts the method of hermeneutic by 'Abd Al Halīm Muhammad Abū Syuqqah associated with his views about the freedom of a Muslim woman. This effort by Abū Shuqqah should be appreciated as a form of his ijtihad to assist and facilitate Muslim women, who in this case, were those living in Egypt at the time. He is concerned about the need to straighten the Islamic teachings related to women, so that modern Muslim women can correctly follow the teachings of Islam.
\end{abstract}

Keywords: Heurmenetics, hadith, Abu Syuqqah

\begin{abstract}
Abstrak
Dalam studi pemikiran Islam zaman modern ini hermeneutika mulai banyak digemari setelah banyak tulisan dan karya yang muncul dari penulis dan cendikiawan Arab kontemporer. Adapun menurut hadis, hermeneutika adalah segala sesuatu yang diambil dari Rasulullah SAW, baik berupa sabda, perbuatan, taqrīr, atau sifat-sifat beliau baik di masa sebelum beliau diangkat menjadi rasul, ataupun sesudahnya. Salah satu tokoh Muslim yang melihat hermeneutika sebagai filsafat tentang bagaimana memahami ayat-ayat Alquran dan Hadis Nabi Muhammad SAW ialah Abū Syuqqah. Penulis pada makalah ini mencoba mengungkap bagaimana Abū Syuqqah menafsirkan dan memberikan pemahaman mengenai hadis nabi Muhammad SAW, serta penulis berusaha untuk menjelaskan struktur hermenetis yang ada dalam pemahaman beliau. Sebagai temuan, penulis mengintisarikan metode hermeneutika pemahaman 'Abd Al Hạlīm Muhammad Abū Syuqqah terkait
\end{abstract}


dengan pandangannya perihal kebebasan yang dimiliki oleh wanita muslimah. Upaya yang dilakukan oleh Abū Syuqqah ini patut diapresiasi sebagai bentuk ijtihad beliau untuk membantu dan memudahkan kaum wanita muslimah, yang dalam hal ini, adalah mereka yang hidup di Mesir pada saat itu. Beliau memperhatikan perlu adanya pelurusan ajaran Islam yang berkaitan dengan wanita, sehingga wanita muslim modern dapat mengikuti ajaran agama Islam dengan lebih tentram.

Kata Kunci : hermeneutika, hadis, Abu Syuqqah

\section{Pendahuluan}

Dalam studi pemikiran Islam zaman modern ini, hermeneutika merupakan trend baru yang sebelumnya tidak mendapat cukup banyak perhatian dari sarjanawan dan cendikiawan muslim. Hermeneutika mulai banyak digemari setelah informasi dan pengetahuan tentangnya banyak menggeliat setelah banyak tulisan dan karya yang muncul dari penulis dan cendikiawan Arab kontemporer.

Hermeneutika (hermeneutics), secara etimilogis berasal dari bahasa Yunani Hermeneuo atau hermeneuien. Dalam tradisi Yunani kuno, kata hermeneuien atau hermeneia (bentuk kata benda) dipergunakan dalam tiga makna, yaitu (1) mengatakan (to say); (2) menjelaskan (to explain); dan (3) menerjemahkan (to translate). Tiga makna inilah yang dalam bahasa Inggris diekspresikan dalam kata "to interpret". Dengan demikian, interpretasi menunjukkan pada tiga hal pokok, pengucapan lisan, penjelasan yang masuk akal, dan terjemahan dari bahasa lain. ${ }^{1}$

Adapun kata hadis, yakni adalah segala sesuatu yang diambil dari Rasulullah SAW, baik berupa sabda, perbuatan, taqrīr, atau sifat-sifat beliau baik di masa sebelum beliau diangkat menjadi rasul, ataupun sesudahnya. ${ }^{2}$

Sahiron Syamsuddin mengatakan, bahwa integrasi hermeneutika (Hermeneutics), yang dalam arti luas mencakup Hermeneuse (praktik penafsiran), hermeneutics (hermeneutika dalam arti sempit, yakni ilmu tentang metode-metode penafsiran), philosopical hermeneutics (hermeneutika filosofis) dan hermeneutical philosophy (filsafat hermeneutis), ke kajian Alquran dan Hadis hingga saat ini masih diperdebatkan di kalangan pemikir Muslim. Banyak dari mereka menolak secara

1 Nasaruddin Umar, Deradikalisasi Pemahaman Alquran dan Hadis (Jakarta: PT Elex Media Komputindo, 2014), hal. 66.

2 Muhammad 'Ajaj Al Khatib, Ushul Al Hadits: Pokok-pokok Ilmu Hadits (Jakarta: Gaya Media Pratama, 2013), cet. 5, hal. 2. 
keseluruhan, sebagian lain menerimanya secara keseluruhan dan sebagian lagi menerima dan atau menolaknya tidak secara keseluruhan. ${ }^{3}$ Maka dengan demikian, hermeneutika hadis adalah upaya memahami, menjelaskan, dan menafsirkan hadis nabi Muhammad SAW.

Beberapa sarjana Muslim yang to some extent menerima Hermeneutika, tentang bagaimana memahami ayat-ayat Alquran dan Hadis Nabi Muhammad SAW antara lain Fazlur Rahman, Mohammed Talbi, Nasr Hamid Abū Zaid, Muhammad Abid Al Jabiri, Aminah Wadud, Muhammad Sabesthari, Muhammad Syahrur, Abdullah Saeed, dan masih banyak lagi. ${ }^{4}$ Salah satu tokoh Muslim yang melakukan upaya tersebut, ialah Abū Syuqqah.

Penulis, pada makalah ini akan membahas mengenai bagaimana Abū Syuqqah menafsirkan dan memberikan pemahaman mengenai hadis nabi Muhammad SAW, serta penulis akan berusaha untuk menjelaskan struktur hermenetis yang ada dalam pemahaman beliau.

\section{Biografi Abū Syuqqah}

'Abd Al Ḥalīm Muḥammad Abū Syuqqah, lahir di kota Kairo, pada 28 Agustus 1924 M atau 28 Muharram 1343 H. Pendidikannya dimulai di Kairo. Beliau belajar beragam ilmu dan pada tahun $1356 \mathrm{H}$ atau $1938 \mathrm{M}$ beliau mendapat Syahādah Al Ibtidā’̀yah, dari Madrasah Al Amīrīyah Li Al Banīn. Kemudian melanjutkan jenjang tsanawīyah-nya di Madrasah Al Taufīqūyah dan langsung melanjutkan di Jämi'ah $F u ` a ̄ d ~ A l$ Awwal. Beliau menjadi sarjana di Kulliyah Al Adab, dengan program studi $A l$ Tārīkh. ${ }^{5}$

Beliau selama masa hidupnya, tinggal di beragam tempat. Beliau pernah tinggal di sebelah masjid kecil milik salah satu asosiasi Islam. Beliau ikut juga dalam kegiatan asosiasi tersebut dan fokus dalam pendidikan individu muslim. Selama belajar di Jāmi'ah, beliau berkenalan dengan dua remaja asal Suriah yang telah menyelesaikan masa belajarnya di Kairo. Beliau kemudian diperkenalkan kepada salah satu guru mereka, yakni Syaikh Khadhr Husain asal Tunisia, yang dulunya pernah menjadi Guru di Al Azhar. Beliau memiliki majelis ilmu yang di dalamnya membicarakan tentang

3 Kurdi dkk, Hermeneutika Alquran dan Hadis, disunting oleh Sahiron Syamsuddin (Yogyakarta: eLSAQ Press, 2010), hal. v.

4 Kurdi dkk, Hermeneutika Alquran dan Hadis, hal. v.

5 Ar.wikipedia.org, Abdul Halim Abū Syuqqah, lihat di situs, http://ar.wikipedia.org/wiki/عبد_الحلي_ أبو_شقة_ diakses pada tanggal 1 Oktober 2015. 
hadis-hadis keagamaan (dīnīyah) dan pendidikan (tarbawīyah) yang beragam. Beliau juga dikenalkan kepada $Q \bar{a} d h \bar{\imath}$ Aḥmad Syākir, seorang qādhì dan penulis dari 'Ishām yang fokus dalam Bahasa Arab dan Syair. Darinya, Abū Syuqqah belajar tentang pentingnya bahasa dan seputar pendidikan dasar dalam menyiapkan diri menjadi seorang individu. Beliau juga dikenalkan kepada Muḥibb Al Dīn Al Khatīb, pemilik dari Majalah Al Fath, yaitu majalah yang membicarakan tentang politik dan agama yang terbuka secara nasional.

Selain itu, Abū Syuqqah juga mengunjungi banyak organisasi Islam, seperti Jam'īyah Al Syar'īyah, Al Madrasah Al Salafìyah, Al Madrasah Al Shūfìyah, Hizb Al Taḥīr Al Islāmī, dan Al Ikhwān Al Muslimīn. Dari semua organisasi yang beliau datangi, pengaruh yang terbesar baginya adalah saat beliau berada di pergerakan $A l$ Ikhwān Al Muslimīn. ${ }^{6}$ Di sana beliau merasakan keterbukaan dalam berdiskusi dengan banyak orang, membahas sesuatu, dan berpikir tanpa ada hambatan atau rasa gugup. Beliau juga banyak melakukan diskusi dengan Syaikh Hassan Al Banna saat pergerakannya dirasa berbahaya karena ajarannya, dan pengurangan kegiatan perpolitikan yang sangat menyempitkan pergerakan mereka. Diskusi tersebut dibangun di atas landasan ilmiah dari banyak pengalaman hidup dan pendidikan yang ditempuhnya, sehingga Abū Syuqqah, selain berdiskusi, juga mempelajarinya. ${ }^{7}$

Bukan hanya hal di atas yang didapat Abū Syuqqah dari dua orang pemuda tersebut, namun juga ada kegiatan ibadah lainnya. Beliau juga ikut dalam ibadah qiyām al lail, ibadah individual, dan tafakkur. Ibadah tersebut beliau jadikan sebagai upaya penting dalam pengamalan pengajaran, dan untuk kebutuhan masyarakat sampai kepada pemuda Muslim yang fokus kepada pengajaran dan pendidikan.

Pada akhir tahun 1940-an, Abū Syuqqah memfokuskan dirinya pada isu-isu pemikiran, pendidikan dan lain hal sebagainya. Padahal saat itu Mesir sedang dalam suasana politik yang tegang, sehingga pendidikan dan pemikiran dipinggirkan. Oleh karena itu, dan untuk menghindarkan para pelajar dari arus militerisasi, ekstremisme, dan kekerasan yang berlangsung, beliau bersama dengan teman-temannya mendirikan sebuah perpustakaan yang diberi nama Maktabah Lajnah Al Syabāb Al Muslim untuk menerbitkan buku-buku dan artikel untuk meningkatkan kesadaran kepada pendidikan

6 'Abd Al Halim Muḥammad Abū Syuqqah, Taḥrīr Al Mar'ah F̄̄ 'Ashri Al Risālah: Dirāsah 'An Al Mar`ah Jāmi’ah Li Nushūshi Al Qur’ān Al Karìm wa Shah̄ịai Al Bukhārī Wa Muslim (Kuwait: Dār Al Qalam, 1999), jilid. 1 hal. 28.

7 Ar.wikipedia.org, Abdul Halim Abu Syuqqah, lihat di situs, http://ar.wikipedia.org/wiki/عبد_الحلي_ أبو_شقة_ diakses pada tanggal 1 Oktober 2015. 
dan pemikiran tersebut. Perpustakaan ini akhirnya diyakini oleh penguasa saat itu sebagai wadah bagi mereka yang anti-pemerintah dan memiliki maksud khusus untuk melawan, maka nama Lajnah Al Syabāb Al Muslim, bersama dengan mereka yang bergAbūng di dalamnya, dengan jumlah anggota 70 orang, ditangkap. Perpustakaan itu ditutup dan semua isinya disita di pertengahan tahun 1950. Kemudian, pada tahun 1953, Abū Syuqqah ditangkap ketika beliau sedang mengajar di Madrasah Al Banāt Al Tsanāwīyah dan dipenjara.

Setelah beliau keluar dari penjara, beliau berpikir untuk pindah dari Mesir. Terlebih adik perempuannya sudah menikah dengan salah satu dari dua pemuda asal Suriah, dan pindah ke sana. Adiknya tersebut sudah bekerja di Ma'had Al 'Arabī Al Islāmī di Damaskus selama setahun. Setelah pindah ke Suriah, pada tahun $1374 \mathrm{H}$ atau 1955 M, beliau pindah ke Qatar. Kemudian pada tahun 1384 H atau 1965 M, beliau pulang kembali ke Mesir. ${ }^{8}$

Muḥammad Al Ghazālī mengatakan bahwa Abū Syuqqah adalah seorang ulama yang sangat mencintai agamanya, menghargai ilmu pengetahuan, ikhlas membela yang hak, tidak suka debat kusir yang banyak dikuasai oleh ulama-ulama tanggung dan lebih memilih cara yang didasarkan pada pemaparan riwayat-riwayat yang disadur dari Al Bukhārī dan Muslim, dan (pada bukunya yang akan dibahas di bawah) sedikit sekali beliau mengemukakan hadis-hadis di luar riwayat kedua periwayat tersebut. ${ }^{9}$

Yūsuf Al Qardhāwī mengatakan bahwa Prof. 'Abd Al Halīm tidak begitu dikenal di kalangan luas, kalangan yang mengenalnya akan merasa kagum dan mengakui kemampuannya dalam berpikir secara tenang dan mendalam. Pandangannya yang kritis, reformis, dan berani mengemukakan apa yang diyakininya benar, sampai pada kejujuran dan sikap istiqamahnya sehingga lahir dan batinnya tetap seirama. Beliau kemudian menegaskan, bahwa beliau sudah mengenal Abū Syuqqah secara baik sejak seperempat abad silam, ketika beliau dan Abū Syuqqah sama-sama bekerja di kementerian pendidikan di Qatar. Sejauh yang Yūsuf Al Qardhāwī ketahui, Abū Syuqqah selalu berbicara jujur, benar, bersih, sopan, halus, jenius, dan kritis. ${ }^{10}$

8 Ar.wikipedia.org, Abdul Halim Abū Syuqqah, lihat di situs, http://ar.wikipedia.org/wiki/عبد الحلي_ أبو شقة. diakses pada tanggal 1 Oktober 2015.

9 Pengantar dari Al Syaikh Muhammad Ā Ghazālī, dalam Abū Syuqqah, Taḥrīr Al Mar'ah F̄̄ 'Ashr Al Risālah, jilid. 1, hal. 6 .

${ }^{10}$ Pengantar dari Yūsuf Al Qardhāwī dalam Abū Syuqqah, Taḥrīr Al Mar ah F̄̄ 'Ashr Al Risālah, jilid. 1, hal. 18 . 
Sebelum membicarakan mengenai pemahaman dan cara hermeneutisnya Abū Syuqqah, penulis akan memaparkan secara singkat kitab beliau yang mengandung pemahaman beliau tersebut, yaitu kitab yang berjudul "Taḥīir Al Mar'ah F̄̄ 'Ashri Al Risālah”.

\section{Kitab Tahrīir Al Mar`Ah Fì 'Ashri Al Risālah}

\section{Latar Belakang Penulisan}

Dari latar belakang penulisan karya tersebut, Abū Syuqqah memulai dengan menyampaikan ketertarikannya untuk melakukan kajian yang mendalam tentang Sìrah Nabawīyah, Sejarah Kehidupan Nabi Muhammad SAW, dengan berdasarkan buku-buku Sunnah agar memiliki pegangan yang kuat. Saat beliau menulis karya tersebut, beliau mengatakan bahwa kisah atau sejarah kehidupan nabi Muhammad SAW belum mendapatkan perhatian yang cukup sehingga banyak sanad yang belum diteliti. Sehingga, masih sulit untuk menentukan mana yang shahịh dan mana yang dha'if sanadnya. Faktor yang mendorong Abū Syuqqah untuk melakukan penelitian sehingga menerbitkan karya tersebut, adalah beliau menyadari adanya kenyataan bahwa Sirah Nabawiyah yang mengetengahkan kehidupan Rasulullah SAW mengandung banyak sekali perkataan, perbuatan, dan taqrīr (ketetapan) yang masuk ke dalam kategori sunnah, sehingga dapat ditiru kaum Muslim dalam kehidupan mereka. Karena itu, menurut beliau, sīrah harus diketengahkan kepada kaum Muslim dengan dalil yang lebih jelas sehingga mereka dapat mengikuti petunjuknya dengan perasaan tenang dan mantap melalui keabsahan dalil-dalil yang dijadikan pegangan. $^{11}$

Setelah melakukan penelitian Sïrah Nabawīyah tersebut, Abū Syuqqah melanjutkan penelitian beliau dengan mulai mempelajari kitab Al Shaḥ̆h Muslim dan Syarḥ-nya dari Al Imām Al Nawāwī. Namun saat menguraikan dan mengelompokkan hadis-hadis tersebut, beliau menemukan sebagian hadis yang bersifat praktis dan operasional, serta berkaitan dengan masalah wanita dan hubungannya dengan lelaki dalam berbagai bidang kehidupan. Beliau menemukan hadis-hadis tersebut dan memahaminya hingga beliau menyimpulkan bahwa hadis tersebut bertolak belakang dengan apa yang beliau pahami dan praktekkan selama ini, bahkan dengan apa yang dipahami dan dipraktekkan oleh berbagai kelompok Islam yang pernah memiliki

\footnotetext{
${ }^{11}$ Abū Syuqqah, Taḥrīr Al Mar `ah F̄̄ ‘Ashr Al Risālah, jilid. 1, hal. 28.
} 
hubungan dengan beliau. Kelompok tersebut terdiri dari berbagai aliran, seperti organisasi Al Syāri'ah, Al Ikhwān Al Muslimīn, kelompok Sufi, kelompok Salaf, Hizb Al Taḥrīr Al Islāmī, dan lain sebagainya. Bahkan hadis-hadis itu, karena dirasa pentingnya, telah membuat Abū Syuqqah ingin membenahi persepsi mengenai karakteristik wanita muslimah dan sejauh mana keterlibatannya dalam berbagai bidang kehidupan pada zaman kerasulan nabi Muhammad SAW. ${ }^{12}$

Karena kuatnya ketertarikan tersebut, maka Abū Syuqqah mengubah haluan pengkajian dari proyek penulisan Sīrah Nabawīyah para proyek pengkajian wanita muslimah pada masa kenabian. Kondisi wanita muslimah pada masa kenabian memberikan gambaran yang jelas sekali tentang udara kebebasan yang dapat dihirup oleh kaum wanita. Abū Syuqqah terdorong karena pernah adanya bahaya besar dan Abū Syuqqah masih rasakan pada saat beliau hidup, yaitu dominasi visi dan persepsi yang bertolak belakang dengan ajaran agama mengenai emansipasi wanita. ${ }^{13}$

\section{Tema dan Metode Penulisan}

Adapun tema penulisan buku tersebut, dari judulnya saja sudah jelas bahwa yang ingin Abū Syuqqah lakukan adalah mengangkat tema-tema yang berkaitan dengan wanita. Buku tersebut merupakan kajian sosial yang memiliki nuansa fiqih sosial mengenai wanita pada masa kerasulan. Abū Syuqqah berupaya untuk memuat semua nash, baik dari Alquran maupun hadis nabi Muhammad SAW, yang mengindikasikan pada wanita, dari dekat ataupun jauh, dalam hal kehidupannya, baik yang sifatnya pribadi maupun umum. Begitu juga dengan hubungan sosial wanita dengan sekeliling serta keanekaragaman kegiatannya di masa tersebut. Hal ini karena, Abū Syuqqah mengatakan, bahwa agama Islam mengatur kehidupan individu, baik lelaki atau wanita, seperti halnya mengatur tatanan masyarakat. Penggabungan antara kajian sosial dan kajian fiqih serta keterkaitan kegiatan sosial dengan dalil-dalil fiqhīyah-nya akan menjadi faktor yang sangat membantu dalam penyelidikan yang menyeluruh terhadap perilaku seorang individu muslim, dalam hal ini adalah wanita muslimah. ${ }^{14}$

Abū Syuqqah berusaha melihat gejala sosial baru yang berpengaruh terhadap kegiatan wanita dan hubungannya, baik dalam keluarga atau dalam bidang profesi,

${ }^{12}$ Abū Syuqqah, Taḥrīr Al Mar'ah F̄̄ 'Ashr Al Risālah, jilid. 1, hal. 28.

${ }^{13}$ Abū Syuqqah, Tahrīr Al Mar'ah F̄̄ 'Ashr Al Risālah, jilid. 1, hal. 30.

${ }^{14}$ Abū Syuqqah, Taḥrīr Al Mar'ah F̄̄ 'Ashr Al Risālah, jilid. 1, hal. 38. 
sosial, dan politik. Begitu juga yang berpengaruh terhadap pakaian wanita dan perhiasannya. Semua itu dimaksudkan beliau agar wanita muslimah dapat menyesuaikan diri secara benar dan dapat bermasyarakat secara modern sambil tetap berpijak pada substansi yang digariskan oleh agama Islam. Dengan demikian, wanita muslimah akan senantiasa konsisten terhadap perintah agama Allah SWT, Islam, dan wanita muslimah modern mendapatkan gambaran dan mengikuti langkah-langkah atau aktivitas wanita masa kerasulan dengan berpedoman petunjuk nabi Muhammad SAW. ${ }^{15}$

Menurut penulis, Abū Syuqqah merasa bahwa emansipasi atau pembebasan pemikiran kalangan muslim modern sudah menjadi hal yang penting untuk diupayakan. Terdapat belenggu pemikiran, ukuran-ukuran palsu, dan pemikiran yang merusak yang telah menguasai umat Islam, sehingga umat menjadi lemah dan rusak. Jika belenggu tersebut telah hilang dan pemikiran umat Islam modern terbebas, segala aktivitas dan kehidupan akan senantiasa sesuai dengan pancaran cahaya hidayah Allah SWT. Pembebasan pemikiran umat Islam merupakan jalan satusatunya, menuju kebebasan yang sempurna dan murni bagi wanita dan lelaki muslim secara sekaligus. ${ }^{16}$

Beliau mulai mempelajari isi kitab Al Shaḥ̄h Al Bukhārī yang berkaitan dengan wanita dan berbagai aspek kehidupannya. Selanjutnya beliau mempelajari kitab $A l$ Shaḥ̄h Muslim, dilanjutkan hingga beliau menamatkan 14 kitab hadis, yaitu $A l$ Shaḥịh Al Bukhārī, Al Shaḥịh Muslim, Sunan Abū Dāwud, Sunan Al Tirmidzī, Sunan Al Nasā’̀̄, Sunan Ibnu Mājah, Al Muwaththa`Al Imām Malik, Zawā'id Shaḥ̄ḥ Ibnu Ḥibbān, Musnad Aḥmad, tiga kitab Mu'jam Al Thabrān̄̄, Musnad Al Bazzār, dan Musnad Abū Ya'lā. ${ }^{17}$

Kemudian, metode Abū Syuqqah dalam menulis kitab tersebut adalah metode tematis yang berkaitan dengan wanita dalam Alquran serta kitab Al Shahīh Al Bukhārī dan Muslim. Abū Syuqqah yakin bahwa penulisan kitab ini adalah sebagai langkah konkret dalam dakwah ke arah pengelompokkan baru terhadap nash Alquran dan Sunnah Nabi Muhammad SAW sesuai dengan tuntutan dan kebutuhan umat Islam yang terus berkembang. ${ }^{18}$

${ }^{15}$ Abū Syuqqah, Tahrīir Al Mar'ah Fì 'Ashr Al Risālah, jilid. 1, hal. 38-39.

${ }^{16}$ Abū Syuqqah, Tahrīir Al Mar'ah Fì 'Ashr Al Risālah, jilid. 1, hal. 39.

${ }^{17}$ Abū Syuqqah, Tahrīr Al Mar'ah Fī 'Ashr Al Risālah, jilid. 1, hal. 40.

${ }^{18}$ Abū Syuqqah, Tahrīr Al Mar' ah Fì 'Ashr Al Risālah, jilid. 1, hal. 42. 


\section{Kesimpulan Tulisan}

Penulis sengaja untuk tidak melampirkan seluruh isi dalam kitab tersebut, akan tetapi akan penulis lampirkan kesimpulan yang dikemukakan oleh Abū Syuqqah mengenai tulisan beliau itu. Kesimpulan atau hasil kajian Abū Syuqqah ini dikelompokkan ke dalam lima bidang sesuai dengan tema yang disusun oleh Abū Syuqqah.

\section{a. Karakteristik Wanita}

1) Wanita muslimah pada masa nabi Muhammad SAW memahami karakteristiknya sebagaimana yang telah digariskan oleh agama Islam yang murni sehingga dia melalui berbagai bidang kehidupannya dengan dasar pemahaman tersebut.

2) Karakteristik wanita tersimpul dalam sabda Rasulullah SAW yang menetapkan dasar-dasar persamaan antara laki-laki dan wanita dengan beberapa kekhususan dalam beberapa bidang. Sabda Rasulullah SAW yang dimaksud adalah,

3) Hadis yang mengatakan bahwa wanita itu "kurang akal dan agama" adalah hadis shahīh yang dipahami dan diterapkan secara keliru oleh banyak orang, sehingga mereka menghapus karakteristik wanita yang telah digariskan oleh Allah SWT dalam Kitab-Nya dan diterangkan oleh Rasulullah SAW dalam Sunnahnya.

\section{b. Pakaian dan Perhiasan}

1) Membuka wajah sudah umum dilakukan pada masa Nabi Muhammad SAW. Kondisi seperti ini merupakan kondisi awalnya. Adapun memakai cadar, sehingga yang terlihat hanya kedua bola mata, merupakan salah satu tradisi/mode/cara berdandan yang menjadi trend pada sebagian wanita sebelum dan sesudah kedatangan Islam.

2) Berdandan secara wajar pada muka, kedua telapak tangan, dan pakaian diperbolehkan agama Islam dalam batas-batas yang pantas dilakukan oleh seorang wanita muslimah.

3) Tidak pernah diwajibkan mengikuti satu mode tertentu dalam berpakaian, yang diwajibkan adalah menutupi badan. Tidak berdosa mengikuti beberapa mode sesuai dengan kondisi cuaca dan lingkungan sosial. 
4) Kriteria-kriteria di atas membantu wanita untuk lebih bebas bergerak dan memudahkannya dalam mengikuti kegiatan sosial.

\section{c. Keterlibatan Wanita dalam Kehidupan Sosial}

1) Sudah jelas bahwa menetap di rumah dan memakai hijab merupakan kekhususan untuk istri-istri nabi Muhammad SAW, sebagaimana juga sudah jelas bahwa sahabat-sahabat wanita (Al Shaḥābīyat) yang mulia tidak mengikuti perbuatan istri-istri Nabi SAW tersebut.

2) Wanita ikut dalam kehidupan sosial dan seringkali bertemu dengan kaum lelaki dalam semua bidang kehidupan, baik yang bersifat umum maupun khusus, guna memenuhi tuntutan dan kebutuhan hidup yang serius dan untuk memberi kemudahan bagi semua orang mukmin, baik lelaki maupun wanita.

3) Keterlibatan ini tidak ada syaratnya selain beberapa tuntunan dan aturan yang mulia dan sifatnya adalah memelihara, bukan menghambat.

4) Wanita terlibat dalam bidang sosial, politik, dan profesi sesuai dengan kondisi serta kebutuhan hidup pada masa kerasulan. Dalam bidang sosial misalnya, wanita muslimah terlibat dalam beberapa bidang seperti kebudayaan, pendidikan, jasa atau pelayanan sosial, dan hiburan yang bijak. Dalam bidang politik, wanita muslimah memiliki keyakinan yang berbeda dengan keyakinan masyarakat dan pihak penguasa. Wanita muslimah menghadapi tekanan dan siksaan, kemudian dia berhijrah untuk membela dan menyelamatkan keyakinannya itu. Di samping itu, wanita muslimah mempunyai perhatian dan rasa peduli terhadap urusan masyarakat umum, mengemukakan pendapat dalam berbagai isu politik, dan kadang-kadang bersikap oposisi dalam bidang politik. Sementara dalam bidang profesi, wanita ikut terlibat dalam bidang pertanian, peternakan, kerajinan tangan, administrasi, perawatan, pengobatan, kebersihan, dan pelayanan rumah tangga. Kegiatan tersebut membantu wanita mewujudkan dua hal, yakni mewujudkan kehidupan yang layak bagi diri dan keluarganya dalam keadaan suaminya sudah tiada, lemah, atau miskin, dan mencapai kehidupan yang lebih mulia dan terhormat, sebab dengan hasil usahanya itu dia mampu bersedekah di jalan Allah SWT.

5) Mengingat semakin seriusnya kondisi sosial pada masa kini yang menuntut semakin ditingkatkannya partisipasi wanita dalam bidang sosial, politik, dan 
profesi, maka kaidah-kaidah dan aturan-aturan yang telah digariskan syariat harus menjadi pengatur kondisi tersebut sampai akhir zaman.

6) Di antara hasil keterlibatan wanita dalam kehidupan sosial tersebut, adalah timbulnya kesadaran wanita, semakin matangnya cara berpikir dan mampunya wanita melaksanakan berbagai kegiatan yang bermanfaat.

\section{d. Keluarga}

1) Menegaskan bahwa wanita berhak memilih suami dan berhak meminta cerai jika dia memang tidak menyukai suaminya, walaupun dia tidak dirugikan oleh suaminya dengan syarat dia mengembalikan apa yang dia ambil dari suaminya dengan ketetapan dari suami atau hakim setelah dibuktikan bahwa dia benarbenar sudah tidak menyukai suaminya.

2) Berbagi tanggung jawab di antara pasangan suami istri dan melakukan kerjasama yang baik patut dilakukan demi sempurnanya pelaksanaan tanggung jawab tersebut.

3) Hak suami dan istri sama. Allah SWT berfirman, yang artinya “...Dan para wanita mempunyai hak yang seimbang dengan kewajibannya menurut cara yang ma`ruf. Akan tetapi para suami, mempunyai satu tingkatan kelebihan daripada istrinya ....”. (Q. S. Al Baqarah (2): 228). Derajat atau satu tingkatan yang dimaksud adalah kepemimpinan suami dalam rumah tangganya atau kelebihan mengalahnya suaminya dari beberapa hak yang harus dia peroleh. Di antara hak-hak tersebut adalah hak dicintai, hak disayangi dan dikasihani, dak berdandan dan menikmati hubungan seksual, serta hak untuk bersama-sama dalam kesibukan dan kesusahan seperti yang dialami oleh setiap pihak.

4) Syariat telah menentukan syarat-syarat dan peraturan mengenai perceraian dan poligami. Keadaan sebuah keluarga muslim tidak akan berjalan dengan baik kalau salah satu syarat dan peraturan tersebut timpang. Karena itu tidak ada salahnya jika pada masa sekarang untuk ditetapkan suatu aturan yang menjamin dipenuhinya semua syarat dan peraturan.

5) Peranan wanita atau istri dalam keluarga merupakan tugas utama dan pertama. Tapi hal ini tidak menafikkan bahwa wanita juga mempunyai kewajiban lain di tengah masyarakat. Tumbuhnya kesadaran bermasyarakat dan adanya kerjasama yang erat antara suami dan istri merupakan dua faktor yang sangat 
penting untuk mengkoordinasikan tugas pertama wanita dengan tugas-tugas lainnya yang dibutuhkan demi terwujudnya kemashlahatan masyarakat muslim sehingga dalam masyarakat terwujud perkembangan positif dan kemajuan yang progresif.

\section{e. Bidang Seksual}

1) Seks merupakan bagian dari kesenangan di dunia dan di akhirat. Seks adalah halal dan baik. Seseorang dapat memperoleh pahala karena melakukan aktivitas seksual yang sesuai dengan batas-batas yang digariskan oleh agama. Persepsi umat Islam perlu diluruskan mengenai masalah ini karena telah dikAbūrkan oleh pemikiran sufistik yang menyimpang dan dilatarbelakangi oleh paham rahbānīyah (kerahiban) dari kalangan Kristen serta sebagian agama Timur Kuno.

2) Nabi Muhammad SAW bersama para sahabatnya berjalan mengikuti jalur yang menuju arah terwujudnya pendidikan seks yang benar dan pengetahuan seks yang bersih dan murni. Hal ini menghasilkan mental yang sehat di kalangan lelaki dan wanita. Perlu dilenyapkan tembok raksasa yang selama ini menghambat dan menutupi segala sesuatu yang ada kaitannya dengan seks.

3) Rasulullah SAW adalah contoh manusia yang sempurna, baik dalam kondisi beristri satu atau pun dalam keadaan berpoligami, baik dari segi sifat zuhud dan kesederhanaannya ataupun dari segi kesempurnaannya dalam bergaul dan berhubungan dengan para istri beliau. Kemudian, setelah membetulkan persepsi mengenai seks secara umum, perlu juga untuk membetulkan persepsi mengenai sikap Rasulullah SAW terhadap seks.

4) Mempermudah proses perkawinan semenjak usia dini merupakan salah satu ciri masyarakat Islam. Alangkah banyak bentuk kemudahan yang telah digariskan Sunnah dalam masalah ini. Dengan penuh tekad dan semangat, harus dibuka jalan kemudahan bagi proses perkawinan pada masa sekarang sesuai dengan apa yang telah digariskan oleh Yang Maha Pencipta, Dia tentu lebih tahu mengenai ciptaan-Nya. Setiap tindakan yang sifatnya mempersulit, hanya akan membuat orang semakin jauh dari menaati Allah SWT sehingga 
semakin dekat pada perbuatan yang tidak perpuji, baik yang terlihat maupun yang terselubung, bahkan mungin terjebak di dalamnya. ${ }^{19}$

Setelah diuraikan secara singkat hasil kajian dalam kitab ini oleh Abū Syuqqah, selanjutnya beliau mengatakan bahwa kita masih dituntut untuk melakukan sejumlah kajian ilmiah jika ingin benar-benar mengulang sejarah keikutsertaan dan dinamika wanita serta membina kembali masyarakat di atas pondasi yang kokoh. Usulan Abū Syuqqah mengenai kajian ilmiah itu mencakup lima bidang, yaitu sebagai berikut:

a. Teks-teks yang bersumber dari Alquran dan Sunnah Rasulullah SAW, tetapi dengan catatan bahwa kajian tersebut harus meliputi seluruh isi kitab Sunnah.

b. Warisan budaya Islam, yakni dengan mengumpulkan pendapat-pendapat dan ijtihad-ijtihad para ulama serta penerapannya secara konkret selama berabad-abad, sehingga betul-betul dipahami sejauh mana pengaruh sejarang yang panjang ini dalam pemikiran dan realita kehidupan.

c. Tulisan-tulisan para cendikiawan muslim modern dengan cara menganalisa semua tulisan mereka dengan segala orientasinya agar kita sampai pada suatu kesimpulan yang bermanfaat dari teori-teori dan ijtihad-ijtihad modern.

d. Penerapan-penerapan yang sedang berlaku di tengah masyarakat sekarang ini, misalnya dengan melakukan kajian ilmiah lapangan dan statistik terhadap masalah-masalah ini sebaik mungkin sehingga kita dapat melakukan evaluasi yang benar, rinci, dan bukan berdasarkan pada kemungkinan-kemungkinan semata.

e. Penelitian-penelitian Barat modern yang berkaitan dengan wanita dalam bidang ilmu jiwa, pendidikan, pengetahuan mengenai seks, kegiatan profesi, sosial, dan politik dengan memberikan perhatian khusus terhadap studi lapangan dan statistika untuk dapat mengetahui keadaan yang sebenarnya, sehingga kita betulbetul mampu menentukan mana yang patut diambil dan mana yang harus ditinggalkan dari pengalaman-pengalaman yang telah dilalui oleh suatu bangsa, setelah menimbangnya dengan timbangan agama. Tidak boleh berpegang pada dugaan-dugaan semata, baik dari kaum modernis ataupun konservatif. ${ }^{20}$

${ }^{19}$ Abū Syuqqah, Taḥrīr Al Mar'ah F̄̄ 'Ashr Al Risālah, jilid. 1, hal. 45-48.

${ }^{20}$ Abū Syuqqah, Taḥrīr Al Mar'ah Fì 'Ashr Al Risālah, jilid. 1, hal. 48-49. 
Selanjutnya, Untuk mengetahui metodologi hermeneutika Abū Syuqqah dalam memahami hadis, akan terlebih dahulu penulis lampirkan salah satu contoh penjelasan Abū Syuqqah dalam topik-topik kajian yang dibahas oleh beliau dalam kitab "Taḥīr Al Mar'ah F̄̄ 'Ashri Al Risālah'. Topik yang akan penulis angkat tersebut, tidak penulis maksudkan untuk mengatakan bahwa topik yang lainnya tidak penting, namun dari topik-topik yang dijelaskan secara ringkas di atas, ada baiknya untuk memaparkan salah satu dari topik tersebut.

\section{Hermeneutika Hadis Abū Syuqqah}

Pemahaman dan metode hermeneutika hadis oleh Abū Syuqqah memang belum pernah diteliti secara langsung, atau setidaknya penulis belum menemukannya. Penulis tahu satu karya beliau yang banyak memuat hasil pemikiran dan pandangan beliau tentang agama Islam. Karya tersebut diberi nama "Tahrīr al Mar'ah F̄̄ 'Ashri Al Risālah". Sebagaimana yang penulis katakan sebelumnya, sebelum mengetahui struktur hermeneutis Abū Syuqqah, akan penulis paparkan secara singkat salah satu pembahasan dalam kitab karangan Abū Syuqqah tersebut. Pembahasan yang ingin penulis paparkan, adalah pembahasan mengenai cadar sebagai penutup wajah untuk wanita.

Dalam mengutarakan pandangan beliau mengenai cadar, beliau menggunakan metode sosio-historis. Terlebih dahulu beliau memaparkan konteks cadar di masa Jahiliyah. Dengan mengutarakan beberapa bait syair di masa jahiliyah, beliau mengindikasikan bahwa niqab/cadar (kerudung yang diikatkan di atas hidung hingga ke leher) sudah dikenal oleh sebagian bangsa Arab sebelum Islam, dan merupakan salah satu model pakaian dan perhiasan wanita. $^{21}$ Setelah Islam datang, Islam tidak memerintahkannya dan tidak melarangnya, akan tetapi membiarkannya menjadi tradisi manusia. Model pakaian pada umumnya diserahkan oleh Syāri' kepada umat Islam untuk memilihnya dengan syarat sesuai dengan kondisi kehidupan mereka secara geografis dan sosial. Juga yang paling penting, adalah mereka mematuhi adab-adab yang telah ditetapkan, apapun model yang dipilihnya. ${ }^{22}$

Abū Syuqqah selanjutnya mengatakan bahwa Islam mengakui cadar dan membolehkannya demi memberikan kelapangan kepada segolongan wanita muslimah yang menjadikan cadar sebagai mode pakaiannya dari satu sisi, dan dari sisi lain karena

${ }^{21}$ Syair-syair yang dikutip Abū Syuqqah berasal dari Umm 'Amr binti Waqdān, Al Abraq, Al Ḥuthai'ah, dan Al Nab̄̄ghah Al Ja'dī. Lihat Abū Syuqqah, Taḥrīr Al Mar'ah F̄̄ 'Ashr Al Risālah, jilid. 4, hal. 215.

${ }^{22}$ Abū Syuqqah, Taḥrīr Al Mar'ah F̄̄ 'Ashr Al Risālah, jilid. 4, hal. 216. 
cadar tidak mengganggu satu kepentingan pun dari kepentingan kaum muslim di dalam masyarakat kecil yang membiasakannya. ${ }^{23}$

Selanjutnya Abū Syuqqah melakukan kontekstualisasi cadar yang dimaksud, dengan cadar pada masa kini. Abū Syuqqah mengatakan bahwa terdapat beberapa karakteristik yang membedakan cadar dari beberapa model pakaian masa kini yang di dalamnya kita lihat sesuatu yang patut diingkari, karena menyebabkan kesempitan dan kesulitan. Karakteristik yang baik tersebut adalah sebagai berikut:

1. Cadar (kain yang diikatkan di atas hidung hingga leher) tidak menutup wajah secara keseluruhan. Sehingga wanita tidak menyembunyikan jati diri dan memberikan kesempatan untuk berkenalan, khususnya di masyarakat kecil seperti masyarakat Badui Kuno. Hal ini dikarenakan anggota masyarakatnya sedikit dan banyak terjadi interaksi sosial di antara mereka, sehingga memudahkan untuk mengenali seorang wanita, meskipun memakai cadar.

2. Oleh karena cadar mentolerir perkenalan, maka mendorong peran serta wanita dalam kehidupan sosial. Sebaliknya, menutup wajah secara total akan mendorong wanita untuk menjauhkan diri dari kehidupan sosial.

3. Karena cadar menampakkan kedua mata dan kedua kelopaknya, maka memungkinkan lawan bicara wanita memahami perasaannya, seperti senang atau susah, ridha atau terganggu, dan menerima atau menolak.

4. Karena cadar menampakkan kedua mata, maka membantu wanita yang lemah untuk menjaga dari rasa malu, jika ia ingin memandang orang yang berlalu lalang. Ini berbeda dengan penutup yang menutup semua wajahnya. ${ }^{24}$

Selanjutnya, Abū Syuqqah menjelaskan cadar dalam pandangan Syariat Islam. Pertama, beliau membahas mengenai hadis tentang "Larangan cadar dalam Ihram dan Petunjuknya". ${ }^{25}$ Hadis tersebut menunjukkan mengenai larangan-larangan dalam

${ }^{23}$ Abū Syuqqah, Taḥrīr Al Mar'ah F̄̄ 'Ashr Al Risālah, jilid. 4, hal. 219.

${ }^{24}$ Abū Syuqqah, Taḥrīr Al Mar'ah F̄̄ 'Ashr Al Risālah, jilid. 4, hal. 219.

${ }^{25}$ Berikut adalah narasi hadis tersebut,

حدثنا عبد الله بن يزيد حدثنا الليث حدثنا نافع عن عبد الله بن عمر رضي الله عنهما قال : قام رجل فقال يا رسول الله ماذا تأمرنا أن نلبس من الثياب في الإحرام ؟ فقال النبي صلى الله عليه و سلم ( لا تلبسوا القميص ولا السراويلات ولا العمائم ولا البرانس إلا أن يكون أحد ليست له نعلان فليلبس الخفين وليقطع أسفل من الكعبين ولا تلبسوا شيئا مسه الزعفران ولا الورس ولا تنتقب المرأة المحرمة ولا تلبس القفازين ) 
berihram, baik bagi lelaki maupun wanita. Semuanya adalah larangan dari bermewahmewah dan berhias diri serta ajakan untuk kesederhanaan. Hal ini berarti bahwa memakai cadar termasuk berhias diri dan bermewah-mewahan yang dibiasakan oleh sebagian wanita. Keadaannya sama dengan sorban, topi, celana, dan khuff bagi lelaki. Model pakaian itu termuat dalam satu konteks dalam hadis tersebut.

Untuk menegaskan bahwa cadar merupakan perhiasan dan kemewahan, Abū Syuqqah memaparkan beberapa hal, yaitu sebagai berikut:

1. Apabila cadar itu menutup sebagian wajah, maka ia menampakkan sebagiannya, khususnya kedua mata. Lalu terkadang, apa yang ditampakkan malah lebih indah dari apa yang disembunyikan, khususnya apabila kedua mata itu dihiasi dengan celak, sedangkan bercelak itu termasuk perhiasan yang biasa dilakukan oleh wanita di masa nabi Muhammad SAW.

2. Berhias, sebagaimana bisa dilakukan dengan membuka, maka dapat juga dilakukan dengan menutup. Misalnya, membuka kepala dan menyisir rambut bagi lelaki merupakan berhias diri, dan menutup kepala dengan sorban, atau dengan tarbus (ghutrah atau 'iqāl) juga merupakan berhias. Demikian pula bagi wanita, jika membukanya dengan diberi suatu perhiasan seperti celak termasuk dalam berhias, maka menutup sebagiannya dengan cadar juga termasuk dalam berhias. Apalagi terkadang cadar itu dihiasi dengan semacam hiasan, maka akan bertambah lagi berhias diri itu.

3. Sesungguhnya pakaian, sebagaimana berbeda-beda dari satu lingkungan dengan lingkungan lain sesuai dengan iklimnya, juga berbeda-beda dalam satu lingkungan sesuai dengan strata masyarakatnya. Ada sejenis pakaian yang biasa dipakai oleh golongan elit, ada pula yang dipakai oleh masyarakat umum, dan ada pula yang dipakai oleh pembantu dan bekas budak. Hal ini juga terjadi di bangsa Arab pada zaman Jahiliyah. Golongan elit lelaki biasa mengenakan selendang dan sarung, ditambah dengan perhiasan, sedangkan golongan umum dan fakir cukup mengenakan sarung (izār) saja. Demikian juga kaum wanita, wanita yang terhormat dan merdeka biasanya memakai cadar bersama dengan pakaian lain seperti jilbab, sedangkan wanita miskin atau budak biasanya memakai pakaian minim dan

Hadis riwayat Abū 'Abd Allāh Muḥammad bin Ismā`̄̄l Al Bukhārī, Al Jāmi' Al Shaḥịh Al Musnad Min Hadīts Rasūli Allāh Shallā Allāhu 'Alaihi Wa Sallam Wa Sunanihi Wa Ayyāmihi (Kairo: Al Mathba'ah Al Salafīyah Wa Maktabatuhā, 1403 H), jilid. 2, kitab Jazā’u Al Shaid, bab Ma Yunhā Min Al Thaiyib Li Al Muhrim Wa Al Muhrimah, hal. 14, hadis. 1838. 
membuka wajahnya. Bahkan terkadang membuka kepalanya sebagai simbol kepapaan. Sebaliknya, bercadar sebagai simbol kemewahan. Setelah memaparkan argumentasi beliau yang berisikan pendapat ulama sebelumnya, Abū Syuqqah menyimpulkan bahwa cadar adalah salah satu model pakaian yang dipergunakan untuk berhias diri oleh sebagian wanita merdeka pada zaman jahiliyah, dan hal itu terus berlangsung hingga sesudah datangnya Islam, karena diakui oleh nabi Muhammad SAW, tetapi tanpa ada dorongan dan anjuran. Seandainya cadar dijadikan sarana untuk menjaga diri dan kesopanan serta sarana untuk memelihara rasa malu wanita, sebagaimana yang didakwakan sebagian orang, maka sudah barang tentu Rasul SAW telah memilih cadar untuk istri-istri beliau, sebab mereka lebih layak untuk diberikan penjagaan diri, kesopanan, dan rasa malu. Namun, dipertegas sekali lagi oleh Abū Syuqqah, bahwa Rasulullah SAW tidak memilih cadar untuk istri-istri beliau. Sahabat-sahabat wanita nabi SAW juga tidak memilihnya untuk mereka sendiri. ${ }^{26}$

Setelah membahas cadar dalam satu pembahasan yaitu cadar dalam Syariat Islam, beliau kemudian menuliskan pembahasan selanjutnya yaitu cadar dalam sejarah Islam. Hal ini beliau lakukan atas dasar untuk memberikan sebagian gambaran praktik sejarah, yakni kajian sosial historis terhadap cadar sebagai model pakaian. Abū Syuqqah berusaha untuk memberikan penjelasan mengenai kekhususan pemakaian cadar, siapa yang biasa memakainya, banyak atau sedikit yang memakai, mengapa cadar dipakai, kapan cadar dipakai, dan kapan pula dilepas. ${ }^{27}$ Dengan pendekatan sosio-historis tersebut, Abū Syuqqah memaparkan sejumlah riwayat, meskipun sanadnya lemah dan majhūl, sebagai sekadar bukti sejarah yang diketahui petunjuk-petunjuknya untuk menentukan karakteristik cadar dan adat-istiadat yang berhubungan dengannya. Abū Syuqqah mengatakan bahwa beliau melakukannya dengan hati-hati dan dengan sadar mengetahui bahwa bukti sejarah tidak menuntut adanya kekuatan sanad sebagaimana yang dituntut oleh dalil-dalil syar' $\overline{\text { yyah }}{ }^{28}$

Abū Syuqqah membagi pembahasan ini kepada tiga bagian. Bagian pertama, adalah mengenai pemakaian cadar oleh Umm Al Mu'minin sesudah diwajibkannya Hijāb. Abū Syuqqah mengutarakan empat riwayat pada bagian ini. ${ }^{29}$ Kemudian beliau

\footnotetext{
${ }^{26}$ Abū Syuqqah, Tahrīr Al Mar'ah F̄̄ 'Ashr Al Risālah, jilid. 4, hal. 220-222.

${ }^{27}$ Abū Syuqqah, Tah̆rīr Al Mar'ah F̄̄ 'Ashr Al Risālah, jilid. 4, hal. 224.

${ }^{28}$ Abū Syuqqah, Tah̆rīr Al Mar'ah F̄̄ 'Ashr Al Risālah, jilid. 4, hal. 224.

${ }^{29}$ Berikut adalah narasi keempat riwayat hadis tersebut,
} 
menjelaskan bahwa dari empat riwayat itu, ada tiga petunjuk yang ditemukan. Pertama, istri-istri nabi Muhammad SAW sesudah difardhukannya hijab, jika mereka keluar rumah, mereka tutup wajah mereka. Ini merupakan hal yang pasti yang didasarkan pada riwayat selain empat riwayat di atas yang tidak diketahui sejauh mana kesahihan sanadnya. Kedua, bahwa memakai cadar itu jarang terjadi di masyarakat Muslim di Mekkah dan di Madinah pada mana nabi Muhammad SAW. Karena itu di dalam hadis itu berulang kali disebut lafal "tanakkur" (merasa heran, sembunyi-sembunyi) yang berkaitan dengan pemakaian cadar. Ini berarti bahwa Umm Al Mu`mininn menutup wajah mereka dalam umumnya keadaan mereka dengan penutup selain cadar, seperti ujung jilbab. Tetapi apabila mereka hendak keluar rumah dengan sembunyi-sembunyi, mereka memakai pakaian yang tidak biasa, dan memakai cadar itu yang menyebabkan mereka bersembunyi, karena cadar biasanya digunakan oleh sebagian wanita Arab pendatang dari luar Mekkah dan Madinah, dan jumlah mereka sedikit. Ketiga, memakai cadar bisa bedampak positif, bisa juga negatif. Meskipun dapat membantu menyembunyikan jati diri si wanita dari lelaki asing, tetapi si wanita memungkinkan orang-orang yang

حدثنا عبد الرحمن بن أبي الرجال عن عبد الله بن عمر قال لما اجتلى النبي صلى الله عليه و سلم صفية رأى عائشة

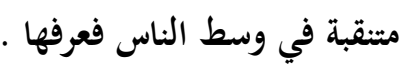

Hadis riwayat Ibnu Sa'ad dalam Al Thabaqāt Al Kubrā, jilid. 8, bab Dzikr Azwāj Rasūli Allāh shallā Allāh 'alaihi wa sallam, hal. 126, dikutip dari CD Al Maktabah Al Syāmilah.

حدثنا أبو بدر عباد بن الوليد ـ حدثنا حبان بن هلال ـ حدثنا مبارك بن فضالة عن علي بن زيد عن أم محم عن عائشة

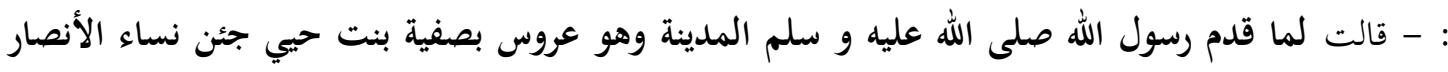

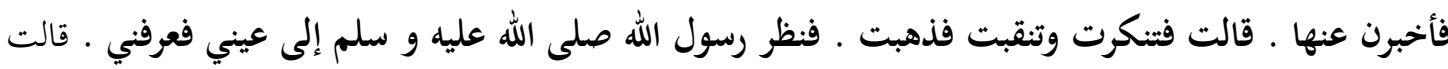

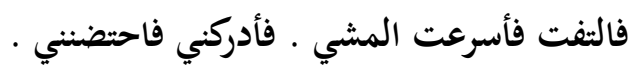

Hadis riwayat Abū 'Abd Allāh Muhammad bin Yazīd Al Qazwainī, dikenal dengan nama Ibnu Mājah, Sunan Ibni Mājah (Al Riyādh: Maktabah Al Ma'ārif Li Al Nasyr Wa Al Tawzī’ Li Shāḥibihā Sa'ad bin 'Abd Al Rạ̣mān Al Rasyīd, Tth), kitab Al Nikāh, hal. 342, hadis. 1980.

أخبرنا محمد بن عمر حدثني عبد الله بن أبي يهيى عن ثبيتة بنت حنظلة عن أمها أم سنان الأسلمية قالت لما نزلنا المدينة لم ندخل منازلنا حتى دخلنا مع صفية منزلها وسمع بها نساء المهاجرين والأنصار فدخلن علئ عليها متنكرات فرأيت أربعا من أزواج النبي صلى الله عليه و سلم متنقبات زينب بنت جحتش وحند وحفصة وعائشة وجويرية

Hadis riwayat Ibnu Sa'ad dalam Al Thabaqāt Al Kubrā, jilid. 8, bab Dzikr Azwāj Rasūli Allāh shallā Allāh 'alaihi wa sallam, hal. 126, dikutip dari CD Al Maktabah Al Syāmilah.

حدثنا محمد بن عبد الله الأسدي حدثنا سفيان عن بن جريج عن الحسن بن مسلم عن صفية قالت رأيت عائشة طافت بالبيت وهي منتقبة .

Hadis riwayat Ibnu Sa'ad dalam Al Thabaqāt Al Kubrā, jilid. 8, bab Dzikr Azwāj Rasūli Allāh shallā Allāh 'alaihi wa sallam, hal. 71, dikutip dari CD Al Maktabah Al Syāmilah. 
bergaul dengannya secara terus-menerus untuk mengenalinya, yakni melalui kedua matanya yang tampak. Namun jika di masyarakat kecil, memakai cadar tidak menimbulkan gangguan karena sedikit dan jarangnya lelaki asing, maka apabila di masyarakat besar dan ramai, memakai cadar dapat menjadi sumber gangguan yang bermacam-macam, yang mana di masyarakat itu diperlukan kejelasan identitas dari setiap orang, baik lelaki maupun wanita. ${ }^{30}$

Bagian kedua, yakni pembahasan mengenai pemakaian cadar oleh sebagian kaum wanita. Di bagian ini, Abū Syuqqah menyampaikan satu khabār dari Al Bukhārī, yang mana menjelaskan bahwa Samūrah bin Jundub memperbolehkan kesaksian wanita yang mengenakan cadar. ${ }^{31}$ Khabār tersebut menyebutkan satu peristiwa faktual di mana seorang wanita mengenakan cadar. Ini mengisyaratkan bahwa menutup wajah dengan cadar sudah dikenal pada masa itu, tetapi sedikit atau jarang memakainya. Karena itu, Al Bukhārī menyebutkan dan menegaskan si wanita mengenakan cadar. Jika memakai cadar merupakan suatu kebiasaan, maka tidak ada dorongan bagi sang periwayat untuk menegaskan pemakaian cadar, sehingga semua wanita, atau hampir semuanya, tertutup wajahnya. Seandainya semua wanita mengenakan cadar, tentu khabār tersebut berbunyi, "Samūrah memperbolehkan kesaksian seorang wanita sedang ia mengenakan cadar", atau "Samūrah memperbolehkan kesaksian kaum wanita sedang mereka mengenakan cadar". ${ }^{32}$ Dalam bagian ini, terlihat bahwa Abū Syuqqah menggunakan pendekatan bahasa dalam menganalisa konteks riwayat tersebut.

Bagian ketiga, yaitu pembahasan mengenai pelepasan cadar secara berkala. Bagian ini dibagi ke dalam tiga topik. Pertama, melepaskan cadar saat tertimpa musibah. Pada bagian ini, Abū Syuqqah memaparkan satu hadis riwayat Abū Dāwud. Pada hadis tersebut, ditunjukkan bahwa cadar itu merupakan hanya semata-mata model pakaian yang dibiasakan sebagian wanita, bukan penutup yang wajib dengan perintah dari pembuat syariat. Pelepasan cadar diperkuat dengan keadaan yang menuntut untuk dijauhinya kemewahan (berhias), sebagai contoh, dalam mengutarakan belasungkawa di saat ada kematian seseorang yang mulia, seperti yang tampak jelas dalam hadis tersebut. Abū Syuqqah menambahkan bahwa hadis itu memiliki kualitas sanad yang lemah,

${ }^{30}$ Abū Syuqqah, Taḥrīr Al Mar'ah Fī 'Ashr Al Risālah, jilid. 4, hal. 225.

${ }^{31}$ Berikut adalah narasi khabar tersebut,

$$
\text { وأجاز سمرة بن جندب شهادة امرأة منتقبة }
$$

Hadis riwayat Al Bukhāri, Al Jāmi' Al Shaḥ̄h, jilid. 2, kitab Al Syahādah, bab Syahādah Al A'mā Wa Amruhu Wa Nikāhuhu, hal. 252.

${ }^{32}$ Abū Syuqqah, Taḥrīr Al Mar'ah F̄̄ 'Ashr Al Risālah, jilid. 4, hal. 226. 
sehingga hadis itu tidak beliau jadikan dalil istinbāth syar', namun sebagai fakta sejarah. Lagi-lagi, beliau menggunakan pendekatan historis pada analisa ini, dengan tambahan pendekatan psikologis untuk menganalisa suasana kejadian dalam hadis itu. ${ }^{33}$

Kedua, melepaskan cadar untuk memperkenalkan diri. Pada bagian ini Abū Syuqqah memaparkan hadis riwayat Ibnu Sa'ad tentang peristiwa di saat Hindun binti 'Utbah dan beberapa orang wanita lainnya masuk Islam. Dalam hadis tersebut, Hindun binti 'Utbah, setelah melakukan bai'at kepada Rasulullah SAW, beliau memperkenalkan diri kepada Nabi SAW dengan membuka cadarnya. Dari hadis itu dijelaskan bahwa untuk melepaskan diri dari kesulitan apabila si wanita hendak memperkenalkan dirinya. Hal ini mengukuhkan bahwa cadar merupakan model pakaian yang mengindikasikan kepada penyembunyian jati diri wanita. Lebih dari itu, juga sebagai lambang kemewahan dan untuk berhias diri. Hal ini juga mengukuhkan bahwa cadar itu bukan penutup yang wajib dengan perintah dari pembuat syariat. Seandainya cadar itu wajib, niscaya Nabi Muhammad SAW melarang Hindun binti 'Utbah untuk melepas cadarnya. ${ }^{34}$

Bagian ketiga, yaitu melepaskan cadar dalam keadaan bahaya dan sebagai peringatan dari kejahatan. Pada bagian ini, Abū Syuqqah mengutarakan syair dari Tawbah Al Khafājī tentang seorang wanita bernama Laila yang secara bertahap melepaskan cadarnya untuk menghindarkan dirinya dari para penduduk kampungnya yang mengganggunya karena memakai cadar. Laila ingin tetap mengenakan cadar untuk menunjukkan kemewahan dan berhias diri, tapi kemudian ia melepaskan cadar di saat bahaya mengancam. ${ }^{35}$

Pada bagian terakhir dalam pembahasan mengenai cadar ini, Abū Syuqqah memberikan beberapa komentar terkait dengan hal tersebut. Komentar beliau itu dibagi ke dalam tiga bahasan. Tiga bahasan itu akan penulis paparkan secara ringkas.

Bahasan yang pertama, adalah komentar Abū Syuqqah bahwa cadar adalah model pakaian yang memiliki beberapa keistimewaan, yaitu antara lain:

1. Di dalam cadar (yang tidak menutup seluruh wajah) terkandung suatu kelembutan wanita. Indera penglihatan tetap berfungsi sebagaimana diciptakan oleh Allah SWT, tanpa penghalang, sehingga wanita dapat melihat manusia dan mengenali segala keindahan ciptaan Allah SWT dengan jelas dan terang.

${ }^{33}$ Abū Syuqqah, Taḥrīr Al Mar'ah F̄̄ 'Ashr Al Risālah, jilid. 4, hal. 226-227.

${ }^{34}$ Abū Syuqqah, Taḥrīr Al Mar'ah F̄̄ 'Ashr Al Risālah, jilid. 4, hal. 227.

${ }^{35}$ Abū Syuqqah, Taḥrīr Al Mar'ah F̄̄ 'Ashr Al Risālah, jilid. 4, hal. 227-228. 
2. Cadar menutup sebagian wajah, dan menampakkan sebagian yang lain, menunjukkan kepada pemakainya hingga batas tertentu, dan membatasi sebagian raut wajah, sehingga memungkinkan untuk mengenali pemakainya jika dilihat berulang kali.

3. Jika pada cadar terdapat penutupan pada sebagian wajah, maka padanya juga terdapat penampakan pada sebagian yang lain. Jika pada penutupan terdapat kesopanan, maka pada yang terbuka ada sedikit penghiasan diri. Terkadang pada yang tampak itu lebih indah dari yang tertutup, dan terkadang pula yang tampak itu malah membangkitkan rasa ingin tahu kaum lelaki untuk melihat yang tersembunyi. ${ }^{36}$

Bahasan yang kedua, adalah Syara' itu berlaku dengan lemah lembut terhadap Wanita. Abū Syuqqah mengatakan, bahwa aurat lelaki itu juga terbatas. Oleh karena itu, ada bagian tubuh yang luas untuk menambah penutupan yang lebih dari aurat untuk melindungi tubuh dari panas dan dingin, atau untuk berhias dan memperindah diri. Sedangkan wanita, maka seluruh badannya adalah aurat kecuali wajah dan kedua telapak tangan serta kedua mata kakinya, sehingga dengan demikian tidak perlu tambahan penutupan untuk kesempurnaan pemeliharaan atau kesempurnaan keadaan. Bila terjadi penambahan maka akan menimbulkan kesempitan dan kesulitan. ${ }^{37} \mathrm{Hal}$ ini dipertegas Abū Syuqqah dengan mengutip ayat ke-78 surah Al Hajj. ${ }^{38}$

Namun jika di dalam penutupan tubuh sebagaimana yang ditetapkan syariat itu terdapat sedikit kesulitan bagi wanita yang berada di daerah tropis, maka ini merupakan suatu perkara yang telah ditetapkan oleh Allah SWT atas anak perempuan bani Adam AS, sedangkan kaum wanita harus ridha dan bersabar terhadap ketentuan Allah SWT. ${ }^{39}$ Dalam hal ini terlihat bahwa Abū Syuqqah lebih moderat.

Selanjutnya, Abū Syuqqah mengatakan bahwa perlu diingat, ketika para Fuqahā menemukan sebagian wanita mengenakan cadar dan membiasakannya sehingga menjadi tradisi bagi mereka, para Fuqaha $\vec{a}$ tidak mengingkarinya, tetapi mereka juga tidak menyatakan kebaikannya, tidak menganjurkannya, dan tidak mendorongnya, bahkan mereka membiarkannya untuk menghargai tradisi dan kebiasaan serta memberikan kelapangan kepada manusia terhadap apa yang mereka biasakan dan

\footnotetext{
${ }^{36}$ Abū Syuqqah, Tahrī̄r Al Mar'ah F̄̄ 'Ashr Al Risālah, jilid. 4, hal. 229.

${ }^{37}$ Abū Syuqqah, Taḥrīr Al Mar'ah F̄̄ 'Ashr Al Risālah, jilid. 4, hal. 229.

${ }^{38}$ Narasi ayat tersebut adalah sebagai berikut:
}

${ }^{39}$ Abū Syuqqah, Taḥrīr Al Mar'ah F̄̄ 'Ashr Al Risālah, jilid. 4, hal. 229.

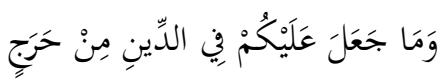


mereka kenali. Sebaliknya, seandainya mereka mengharamkan cadar dan mewajibkan untuk melepasnya, tentu juga akan menyempitkan dan menyulitkan mereka. ${ }^{40}$ Dalam hal ini juga terlihat bahwa Abū Syuqqah condong berpikiran lebih moderat.

Abū Syuqqah kemudian mengkritik penutupan wajah pada masa kini. Beliau mengatakan bahwa penutupan wajah pada masa kini oleh sebagian masyarakat Islam, adalah menutupi semua wajah dan tidak ada yang tampak sedikit pun dari wajah, dan menyempitkan indera penglihatan dan sarana pernapasan bagi wanita. Hal ini, beliau katakan, seharusnya diingkari jika keadaannya malah menyulitkan dan mengganggu wanita. Tidak mungkin dapat dikatakan bahwa yang demikian itu termasuk pakaian wanita yang ditetapkan Nabi Muhammad SAW. Sebab, Rasulullah SAW hanya mengakui cadar yang sudah dikenal pada zaman beliau, dan yang termasuk kemewahan dan berhias diri bagi sebagian wanita. Seandainya Rasulullah SAW melihat penutup wajah masa kini dan melihat kesulitan yang dialami wanita karena memakainya, niscaya beliau akan mengharamkannya dan memilih yang lebih mudah untuk mereka. ${ }^{41}$ Hal ini dikuatkan Abū Syuqqah dengan mengutip hadis riwayat Muslim dari Āisyah RA. $^{42}$

Bahasan yang terkahir pada bagian ini, adalah komentar Abū Syuqqah mengenai pertanyaan, apakah sudah tiba waktunya bagi kita untuk membebaskan diri dari belenggu taklid? Pada bahasan ini, Abū Syuqqah terlebih dahulu mengutip perkataan seorang penyair pada permulaan abad keempat belas Hijriah (abad ke-20 M) yang memandang bahwa cadar sudah menjadi tradisi bagi wanita Mesir. ${ }^{43}$ Pada bahasan ini secara implisit, Abū Syuqqah mengatakan bahwa sudah saatnya untuk membebaskan diri dari taklid buta.

${ }^{40}$ Abū Syuqqah, Taḥrīr Al Mar'ah F̄̄ 'Ashr Al Risālah, jilid. 4, hal. 229.

${ }^{41}$ Abū Syuqqah, Taḥrīr Al Mar'ah F̄̄ 'Ashr Al Risālah, jilid. 4, hal. 230.

42 Narasi hadis tersebut adalah sebagai berikut:

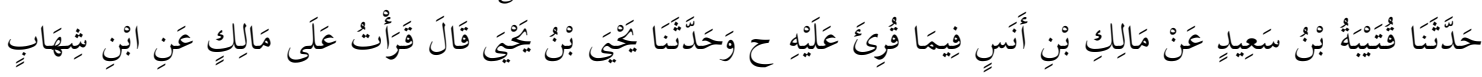

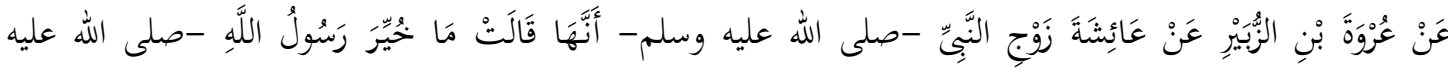

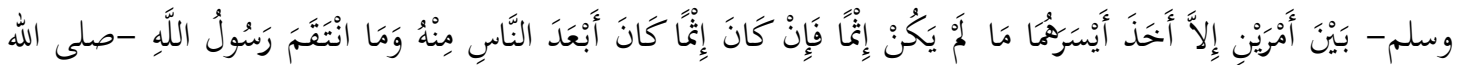

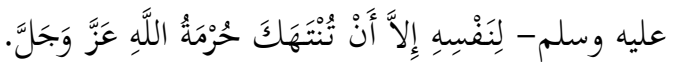

Hadis Riwayat Muslim, Shaḥ̄ḥ Muslim Bi Syarh Al Nawāwī (Kairo: Al Mathba'ah Al Mishrīyah Bi Al Azhar, 1347 H/1929 M), jilid. 15, bab Muba'ādatuhu shallā Allāhu 'alaihi wa sallam li al ātsām wa ikhtiyāruhu min al mubāḥ ashālihi, hal. 83.

${ }^{43}$ Abū Syuqqah, Taḥrīr Al Mar'ah F̄̄ 'Ashr Al Risālah, jilid. 4, hal. 230. 
Pada bagian penutup dari pembahasan tentang cadar ini, Abū Syuqqah menulis sebuah doa agar semoga Allah SWT menyelamatkan kita dari belenggu taklid, taklid kepada nenek moyang tanpa petunjuk dan keterangan, dan beliau memohon untuk diberikan petunjuk melalui Alquran dan Sunnah, dan meneladani dengan baik para Sahabat wanita yang membuka wajah mereka di hadapan Nabi Muhammad SAW dan para Sahabat beliau. ${ }^{44}$

Pada pembahasan selanjutnya di bagian terpisah pada jilid kitab yang sama, Abū Syuqqah menuliskan dialog yang beliau lakukan dengan para penentang pendapat beliau yang mana mereka memandang bahwa menutup wajah secara seluruhnya adalah sebuah kewajiban. Kemudian di bagian kedua, berisikan dialog beliau dengan mereka yang menganjurkan penutup wajah. Di pembahasan ini beliau tulis dalam 47 halaman di kitabnya. ${ }^{45}$ Karena banyaknya pembahasan tersebut maka penulis tidak memaparkannya di tulisan ini.

Demikian penulis paparkan secara ringkas pembahasan Abū Syuqqah mengenai cadar. Dari paparan atas pandangan-pandangan Abū Syuqqah dalam kitabnya, penulis menemukan beberapa hal, yaitu sebagai berikut:

1. Abū Syuqqah dengan kitab ini berusaha untuk menguraikan dan mengelompokan hadis-hadis yang berkaitan dengan masalah wanita dan hubungannya dengan lelaki dalam berbagai bidang kehidupan. ${ }^{46}$

2. Abū Syuqqah setelah memahami berbagai hadis itu, beliau datang sebagai pengkritik atas pemahaman dan praktek berbagai kelompok keagamaan di Mesir seperti Jāmi'ah Al Syāri'ah, Al Ikhwān Al Muslimīn, kelompok Sufi, kelompok Salaf, Hizb Al Taḥīr Al Islāmī, dan lain sebagainya yang mana dinilai oleh Abū Syuqqah bertentangan dengan apa yang beliau pahami dari hadis itu.

3. Abū Syuqqah menulis kitab tersebut dengan tujuan sebagai langkah konkret dalam dakwah ke arah pengelompokkan baru terhadap Alquran dan Sunnah Nabi Muhammad SAW sesuai dengan tuntutan dan kebutuhan umat Islam yang terus berkembang, dan meluruskan pemahaman yang menurutnya salah dengan mengembalikan kepada Alquran dan Sunnah Nabi Muhammad SAW.

4. Dalam menjelaskan pemahaman beliau terhadap hadis, Abū Syuqqah menggunakan metode tematis, dengan pendekatan-pendekatan, antara lain pendekatan sosio-

${ }^{44}$ Abū Syuqqah, Taḥrīr Al Mar'ah F̄̄ 'Ashr Al Risālah, jilid. 4, hal. 230.

${ }^{45}$ Abū Syuqqah, Tahrīr Al Mar'ah F̄̄ 'Ashr Al Risālah, jilid. 4, hal. 285-332.

${ }^{46}$ Lebih khusus dibahas oleh Abū Syuqqah dalam satu jilid pembahasan yaitu pada jilid kedua. 
historis, pendekatan bahasa, pendekatan dialog, dan pada beberapa bagian menggunakan pendekatan psikologis dan pendekatan statistik dan studi lapangan. ${ }^{47}$

5. Dalam memaparkan suatu pembahasan, Abū Syuqqah menjelaskan hadis yang terkait, konteks hadis pada saat hadis itu ada, dan beliau juga melakukan kontekstualisasi hadis itu untuk aplikasinya di masa kini. ${ }^{48}$

Dari pemaparan singkat di atas, maka dapat diperhatikan bahwa latar belakang dan kondisi sosial dan masyarakat saat Abū Syuqqah hidup, berpengaruh kepada pandangan yang beliau miliki. Beliau juga memperhatikan tradisi, kultur, dan pengalaman hidupnya, sehingga beliau merasa perlu untuk melakukan kritik atas apa yang beliau rasa salah dari pandangan sebagian golongan umat Islam.

Kemudian Abū Syuqqah meletakkan dirinya sebagai seorang kritikus yang berusaha untuk berlaku moderat, sehingga beliau dalam pandangannya mengenai wanita dan kehidupannya, berasumsi di awal bahwa nash Alquran dan Hadis nabi Muhammad SAW mengisyaratkan bahwa wanita muslimah pada masa kenabian memberikan gambaran yang jelas dan terang tentang kebebasan yang dimiliki oleh wanita, sehingga ajaran agama Islam berjalan beriringan dengan semangat emansipasi wanita, baik sebagai seorang individu, maupun sebagai anggota dalam sebuah komunitas masyarakat.

Dalam membahas berbagai macam bahasan dalam kitabnya, Abū Syuqqah menggunakan berbagai macam pendekatan, salah satunya adalah pendekatan historis. Dengan demikian Abū Syuqqah juga memperhatikan horison historis yang melingkupi teks, dalam hal ini adalah hadis Nabi Muhammad SAW. Beliau juga melakukan kontekstualisasi dengan masa kini, sehingga horison sang pembaca, dalam hal ini adalah Abū Syuqqah, juga telah diperhatikan oleh beliau.

Abū Syuqqah, seperti yang dapat diperhatikan dalam contoh bahasan mengenai cadar, juga menemukan makna yang dimaksud dari beberapa teks hadis pada saat teks

${ }^{47}$ Contoh dari pendekatan sosio-historis terdapat di Abū Syuqqah, Taḥrīr Al Mar 'ah F̄̄ 'Ashr Al Risālah, jilid. 4, hal. 215-230.

Contoh dari pendekatan bahasa terdapat di Abū Syuqqah, Taḥrīr Al Mar'ah F̄̄ 'Ashr Al Risālah, jilid. 4, hal. 226.

Contoh dari pendekatan psikologis terdapat di Abū Syuqqah, Taḥrīr Al Mar'ah F̄̄ 'Ashr Al Risālah, jilid. 4, hal. 323.

Contoh dari pendekatan statistik dan studi lapangan terdapat di Abū Syuqqah, Tahrī̄r Al Mar'ah Fī 'Ashr Al Risālah, jilid. 4, hal. 324-325.

${ }^{48}$ Hal ini dapat dilihat dengan jelas di sebagian kitab beliau, salah satunya di satu bagian khusus tentang Dialog dengan Para Penentang yang mengatakan dianjurkannya penutup wajah, Abū Syuqqah, Taḥrīr Al Mar'ah F̄̄ 'Ashr Al Risālah, jilid. 4, hal. 323-332. 
tersebut muncul. Kemudian beliau melakukan pengembangan penafsiran atau reaktualisasi dengan tetap memperhatikan kesinambungan "makna baru" ini dengan makna asal dari teks hadis tersebut.

Dari pemaparan di atas pula, diperlihatkan bahwa Abū Syuqqah telah melakukan sebuah perkembangan yang melebihi dibandingkan dengan ulama-ulama di masa beliau. Pada masa beliau, banyak ulama yang belum berpikir sebagaimana beliau. Para ulama tersebut belum memperhatikan aspek lain selain teks atau nash. Dalam hal ini, Abū Syuqqah bukan hanya memperhatikan teks, namun juga telah memperhatikan halhal di luar teks tersebut. Hal ini akan penulis gambarkan sebagai berikut:

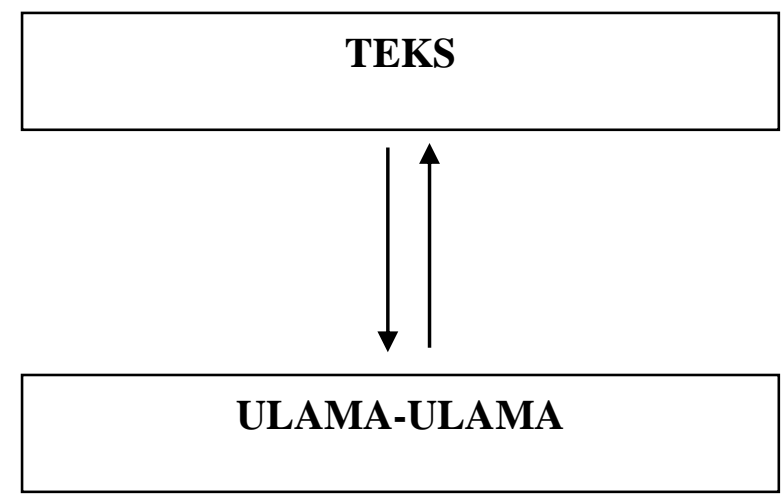

Di atas adalah penggambaran atas apa yang dilakukan oleh Ulama-ulama yang dikritik oleh Abū Syuqqah. Adapun apa yang dilakukan oleh Abū Syuqqah akan digambarkan sebagai berikut:

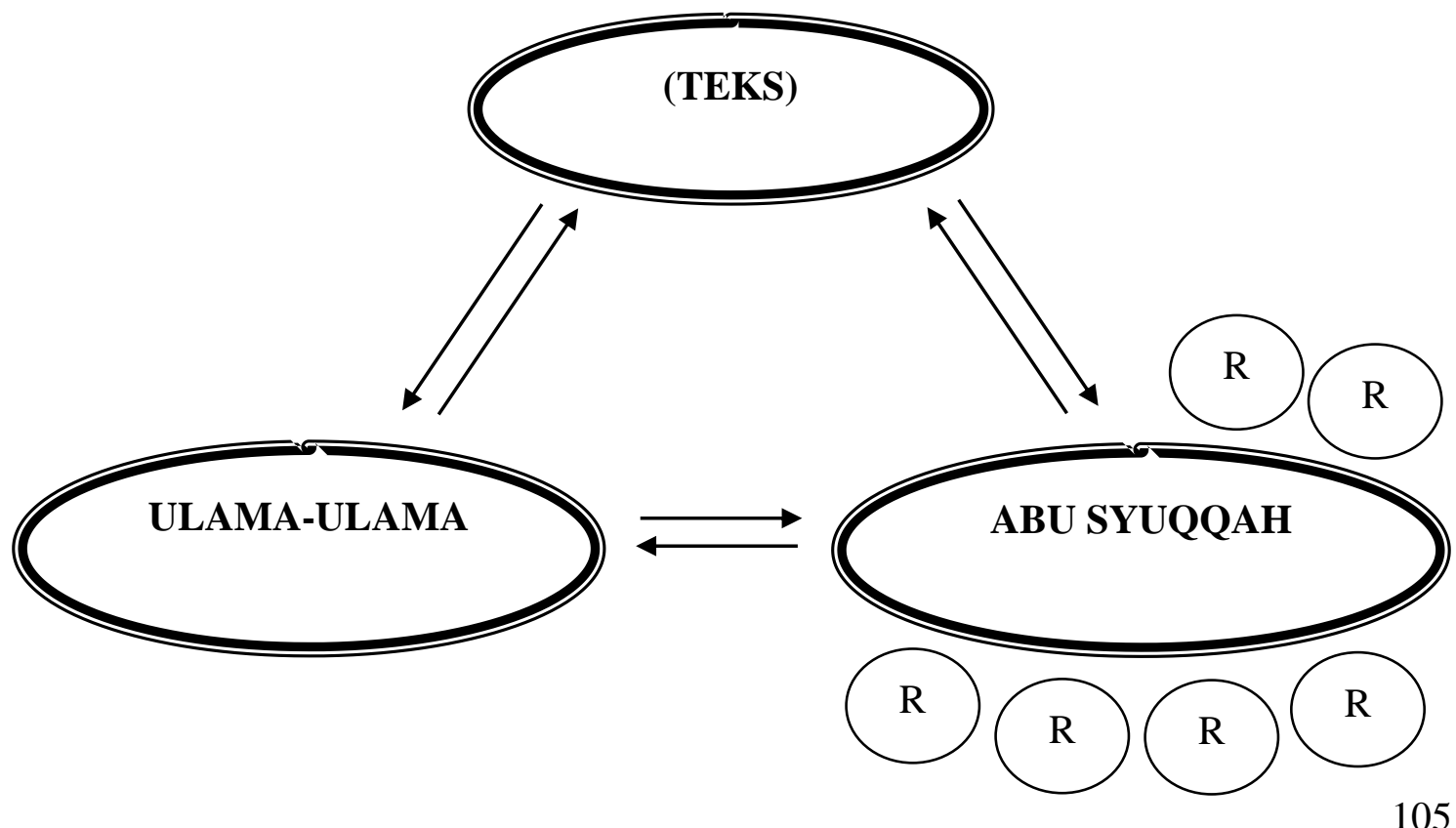


Abū Syuqqah telah memperhatikan realitas-realitas (R) yang ada di sekitar beliau. Beliau menyadari bahwa banyak yang juga harus diperhatikan, antara lain, aspek psikologi, aspek sosial, aspek sejarah, dan aspek pendidikan. Beliau memperhatikan aspek psikologi bagi sang wanita, sehingga beliau berusaha untuk membuat wanita muslimah nyaman dan tentram dengan apa yang ingin wanita itu lakukan. Akan tetapi tetap memperhatikan landasan-landasan agama yang memberikan arahan dalam hidupnya. Sehingga bukan hanya terketat dan terkutat dalam teks yang agama berikan, namun juga memperhatikan apa yang ada di luar teks tersebut. Dari hal inilah kemoderatan yang ada dalam pandangan-pandangan Abū Syuqqah. Dari pemarapan di atas pula, terlihat telah ada sebuah sistem hermeneutis yang dilakukan oleh Abū Syuqqah, yakni mengenai tiga hal, teks, konteks, dan kontekstualisasi yang saling dikaitkan dan dihubungkan menjadi sebuah pemahaman. Demikian pembahasan mengenai hermeneutika hadis Abū Syuqqah. Namun sebagaimana perkembangan ilmu yang niscaya, Abū Syuqqah juga mendapat kritikan dari sebagian ulama lainnya. Berikut akan dibahas mengenai kritik terhadap Abū Syuqqah oleh Sulaimān bin Shālih Al Khurāsyī.

\section{Kritik atas kitab "taḥrīr al mar'ah fī 'ashri al risālah"}

Pada bagian ini, penulis ingin menyampaikan, walaupun tidak berhubungan dengan hermeneutikanya, bahwa Abū Syuqqah dalam menyampaikan pemahamannya dalam kitab "Taḥrīr Al Mar 'ah Fì 'Ashri Al Risālah”, juga tidak terlepas dari kritikan para cendikiawan lainnya. Salah satunya adalah Sulaimān bin Shālị̣ Al Khurāsȳ̄, yang mengatakan dalam sampul artikel beliau, “...hādzā al kitāb al sayyi ”, 49

Dalam artikel yang ditulis oleh Sulaimān bin Shālih Al Khurāsȳ̄, yang berjudul "Naqd Kitāb Taḥrīr Al Mar'ah F̄̄ 'Ashri Al Risālah Li Mu'allifihi 'Abd Al Halīm Abū Syuqqah" tersebut, ada kritik-kritik atas kitab Abū Syuqqah yang berjudul "Taḥrīr Al Mar'ah $F \bar{l}$ 'Ashri Al Risālah'. Artikel dengan 26 halaman ini berusaha untuk menyampaikan dan mengkritik pandangan-pandangan Abū Syuqqah, yang menurut sang penulisnya, yakni Al Khurāsȳ̄, adalah salah. Al Khurāsȳ̄ mengatakan:

${ }^{49}$ Kalimat lengkapnya adalah, "Wa fỉhi Al Tanbīh 'Alā Khatha` Ahad Al Afādhil Fì Ihālatihi 'alā hādzā al kitāb al sayyì.". dalam Sulaimān bin Shāliḥ Al Khurāsyī, artikel dengan judul Naqd Kitāa "Taḥrīr Al Mar’ah F̄̄ 'Ashri Al Risālah” Li Mu`allifihi 'Abd Al Halìm Abū Syuqqah, hal. 1. 


$$
\begin{aligned}
& \text { ولم أكن لأحفل هذا الكتاب الذي كنت أراه خاصاً بهذه الفئة المتبعة لأهوائها سواء في هذا } \\
& \text { الموضوع أو غيره؛ خاصاً بها دون سواها من متبعي الكتاب والسنة، فكنت أراه قاصراً عليهم لا يتعداه إلى لى } \\
& \text { غيرهم من دعاة الإسلام ممن سيعلم بطلان كثير مما جاء فيه بداهة؛ لكونه يخالف آيات الكتاب وأحاديث } \\
& \text { المصطفى م وعمل الصحابة رضي الله عنهم، مهما ادعى مؤلفه ومروجوه خلاف ذلك. إلا أني تفاجأت } \\
& \text { عندما قرأت مقالاً لأحد الفضلاء يتحدث فيه عن المرأة وأفا إنسان !! وأفها تعيش "تحت وصايات } \\
& \text { مشددة -دينياً واجتماعياً وسياسياً- لا تتناسب مع حجم الطاقات والقدرات والإمكانات التي منحها الله } \\
& \text { للمرأة" !! وأننا نخلط "العادات بالعبادات وتقديس الموروثات الآبائية" في موضوع المرأة ! وأننا مع الانفتاح } \\
& \text { أصبح الواحد منا يفاجأ "بأن كثيراً مما كان يملى عليه بكرة وأصيلاً ما هو إلا رؤى مذهبية في أحسن } \\
& \text { أحوالها" !! ثم نقد هذا الفاضل من "يحرسون الفضيلة" بتركيزهم على الحجاب ! مع نسيان الأمور الأخرى } \\
& \text { !... الخ مقاله الذي يذكرك (بغمغمة) الحداثيين والتغريبين ! الذين يلجئون إلى مثل هذه الرموز التي لا } \\
& \text { توصل القارئ إلى ما يريده الكاتب (بوضوح). إنما تفيدك بأن الكاتب مغتاظ وناقم من وضع المرأة !! } \\
& \text { لكن: من أي شيء هو مغتاظ وناقم ؟ هذا ما لا تستفيده من كلماته ! } 50
\end{aligned}
$$

Satu paragraf di atas adalah apa yang dikatakan oleh Al Khurāsyī dalam pengantar kritikan beliau tersebut. Dari pendapat beliau di atas, terdapat beberapa hal yang beliau kritik, antara lain (1) Abū Syuqqah berlaku subjektif, (2) Abū Syuqqah hanya melihat satu golongan saja, yakni wanita saja, (3) Abū Syuqqah hanya memperhatikan untuk kebaikan wanita dan seolah-olah wanita tidak pernah salah, (4) Saat membahas tentang Hijāb, Abū Syuqqah hanya memperhatikan dari sisi tujuan "untuk menjaga kehormatan" dan tidak membahas dari perkara-perkara lainnya, (5) Secara inplisit, Abū Syuqqah telah mengikuti kaum Modernis dan Barat, (6) Abū Syuqqah secara emosional, marah, dan murka dalam menulis kitab itu, (7) Karena kondisi emosional itu, maka Abū Syuqqah tidak jelas tujuannya apa dalam menulis kitab itu, dan (8) Sehingga dengan demikian, maka kitab itu tidak ada manfaatnya.

Al Khurāsyī masih melanjutkan kritikannya pada halaman-halaman selanjutnya, namun penulis sengaja tidak memaparkan satu persatu guna fokusnya tulisan ini. Setidaknya, beberapa penilaian di atas dapat dijadikan sebagian kesimpulan dalam kritik Sulaimān bin Shālị̣ Al Khurāsyī atas Abū Syuqqah yang menulis kitab "Taḥrīr Al Mar`ah F̄̄ 'Ashri Al Risālah’. 50 Sulaimān bin Shāliḥ Al Khurāsȳ̄, artikel dengan judul Naqd Kitāb “Tahrīr Al Mar'ah F̄̄ 'Ashri Al
Risālah” Li Mu'allifihi 'Abd Al Halīm Abū Syuqqah, hal. 2 . 


\section{Penutup}

\section{Kesimpulan}

Demikian apa yang penulis temukan dan pandangan penulis mengenai upaya menemukan metode hermeneutika pemahaman 'Abd Al Halīm Muḥammad Abū Syuqqah terkait dengan pandangannya perihal kebebasan yang dimiliki oleh wanita muslimah. Upaya yang dilakukan oleh Abū Syuqqah ini patut untuk diapresiasi sebagai bentuk ijtihad beliau untuk membantu dan memudahkan kaum wanita muslimah, yang dalam hal ini, adalah mereka yang hidup di Mesir pada saat itu. Beliau memperhatikan perlu adanya pelurusan ajaran Islam yang berkaitan dengan wanita, sehingga wanita muslim modern dapat mengikuti ajaran agama Islam dengan lebih tentram. 


\section{Daftar Pustaka}

Bukhārī, Abū 'Abd Allāh Muḥammad bin Ismā`̄il Al. 1403 H. Al Jāmi' Al Shaḥ̄h Al Musnad Min Hadīts Rasūli Allāh Shallā Allāhu 'Alaihi Wa Sallam Wa Sunanihi Wa Ayyāmihi. Kairo: Al Mathba'ah Al Salafìyah Wa Maktabatuhā.

Khatib, Muhammad 'Ajaj Al. 2013. Ushul Al Hadits: Pokok-pokok Ilmu Hadits. Jakarta: Gaya Media Pratama.

Kurdi dkk. 2010. Hermeneutika Alquran dan Hadis. Yogyakarta: eLSAQ Press.

Mājah, Abū 'Abd Allāh Muḥammad bin Yazīd Al Qazwainī, Ibnu. Tth. Sunan Ibni Mājah. Al Riyādh: Maktabah Al Ma'ārif Li Al Nasyr Wa Al Tawzī' Li Shāḥibihā Sa'ad bin 'Abd Al Raḥmān Al Rasyīd.

Muslim. 1347 H/1929 M. Shaḥịh Muslim Bi Syarh Al Nawāwī. Kairo: Al Mathba'ah Al Mishrīyah Bi Al Azhar.

Syamsuddin, Sahiron, dkk. 2009. Upaya Integrasi Hermeneutika Dalam Kajian Qur'an dan Hadis: Teori dan Aplikasi. Yogyakarta: Lembaga Penelitian Universitas Islam Negeri Sunan Kalijaga.

Syuqqah,'Abd Al Ḥalīm Muḥammad Abū. 1999. Taḥrīr Al Mar'ah Fì 'Ashri Al Risālah: Dirāsah 'An Al Mar’ah Jāmi'ah Li Nushūshi Al Qur'ān Al Karīm wa Shah̄ịai Al Bukhārī Wa Muslim. Kuwait: Dār Al Qalam.

Umar, Nasaruddin. 2014. Deradikalisasi Pemahaman Alquran dan Hadis. Jakarta: PT Elex Media Komputindo.

APLIKASI/CD PUSTAKA

Sa'ad, Ibnu, Al Thabaqāt Al Kubrā, CD Al Maktabah Al Syāmilah.

ARTIKEL

Khurāsȳ̄, Sulaimān bin Shālih Al. artikel dengan judul Naqd Kitāb "Taḥīr Al Mar'ah F̄̄ 'Ashri Al Risālah”' Li Muallifihi 'Abd Al Halīm Abū Syuqqah.

\section{SITUS INTERNET}

ar.wikipedia.org 